\title{
Article \\ Corrosion-Fatigue Life Prediction Modeling for RC Structures under Coupled Carbonation and Repeated Loading
}

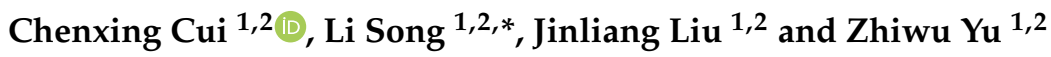 \\ 1 School of Civil Engineering, Central South University, Changsha 410075, China; cui-chx@csu.edu.cn (C.C.); \\ xactor@csu.edu.cn (J.L.); zhwyu@csu.edu.cn (Z.Y.) \\ 2 National Engineering Laboratory for High Speed Railway Construction, Changsha 410075, China \\ * Correspondence: songli@csu.edu.cn
}

Citation: Cui, C.; Song, L.; Liu, J.; Yu, Z. Corrosion-Fatigue Life Prediction Modeling for RC Structures under Coupled Carbonation and Repeated Loading. Mathematics 2021, 9, 3296. https://doi.org/10.3390/math9243296

Academic Editors: Sy-Ming Guu and Mario Versaci

Received: 15 November 2021 Accepted: 17 December 2021 Published: 18 December 2021

Publisher's Note: MDPI stays neutral with regard to jurisdictional claims in published maps and institutional affiliations.

Copyright: (c) 2021 by the authors. Licensee MDPI, Basel, Switzerland. This article is an open access article distributed under the terms and conditions of the Creative Commons Attribution (CC BY) license (https:// creativecommons.org/licenses/by/ $4.0 /)$.
Abstract: The coupled action of concrete carbonation and repeated loading strongly influences the safety of reinforced concrete (RC) structures and substantially reduces service life. A novel corrosionfatigue life prediction model for RC structures under coupled carbonation and repeated loading was developed. The effect of fatigue damage on concrete carbonation and carbonation-induced corrosion rate was considered, and the acceleration of fatigue damage accumulation due to reinforcement corrosion was considered in this approach. The proposed corrosion-fatigue life prediction model was illustrated by a $6 \mathrm{~m}$-span RC slab in a simply supported slab bridge for the highway, and the effects of traffic frequency, overloading, carbonation environment grade, and environmental temperature and relative humidity on corrosion-fatigue life were discussed. The results indicate that the proposed model can predict the corrosion-fatigue life of RC structures simply and conveniently. Traffic frequency, overloading, carbonation environment grade, $\mathrm{M}$ temperature and relative humidity can decrease the corrosion-fatigue life of the RC slab by up to $66.86 \%, 58.90 \%, 77.45 \%$, and $44.95 \%$, respectively. The research is expected to provide a framework for the corrosion-fatigue life prediction of RC structures under coupled carbonation and repeated loading.

Keywords: reinforced concrete structures; corrosion-fatigue life; coupled action; fatigue damage; carbonation-induced corrosion; simply supported slab bridge

\section{Introduction}

Concrete is the most widely utilized building construction material for the development of infrastructures due to its cost, technical properties, and durability characteristics [1,2], and reinforced concrete (RC) structures are the most common structural form in civil engineering. Many RC structures or members, such as highway and railway bridges, crane beams of industrial plants, and offshore oil production platforms not only bear static loads but also bear repeated loads such as vehicle loads, crane loads, or wave loads [3]. Repeated loading will cause fatigue damage in materials. Moreover, fatigue failure, one of the main failure modes of RC structures, will occur with the continuous accumulation of fatigue damage [4,5]. These RC structures also bear the long-term action of the environment, such as carbonation environment and chloride environment. After a period of service, rebar corrosion caused by concrete carbonation or chloride ion ingress commonly occurs in RC structures or members [6-8]. Reinforcement corrosion will cause the bearing capacity degradation of RC structures. Both repeated loading and environmental action will cause material deterioration in RC structures. Fatigue damage and reinforcement corrosion are the dominant reasons for the performance degradation of RC structures $[9,10]$. The fatigue failure mechanism of corroded RC structures is more complex than that of RC structures without corrosion. The reason is that the failure of RC structures caused by the combined action of corrosion and fatigue is not a simple superposition of these two failure factors, but a coupled process of their mutual influence [11]. 
Concrete carbonation is the primary factor that causes the reinforcing bar corrosion of RC structures exposed to an atmospheric environment. With the accelerating process of global industrialization, the concentration of carbon dioxide $\left(\mathrm{CO}_{2}\right)$ in the air is increasing, and the carbonation of RC structures is becoming increasingly serious [12,13]. Concrete carbonation refers to $\mathrm{CO}_{2}$ ingression concrete interior and neutralization with alkaline substances. Carbonation will decrease the $\mathrm{pH}$ value of concrete, leading to reinforcing bar depassivation [14]. Then, reinforcement corrosion will occur in the presence of oxygen and water. Repeated loading will lead to a rapid accumulation of fatigue damage in concrete, and fatigue damage will accelerate the transport of aggressive agents into concrete [15]. The tensile performance of concrete material is weak, and fatigue cracks are easy to generate and propagate under repeated loading. The transport path enlarged by concrete fatigue cracking further accelerates the transport of aggressive agents in concrete and causes reinforcing bars to corrode earlier and faster [16,17]. When the reinforcing bar is corroded, the cross-sectional area of the reinforcing bar decreases, resulting in a decrease in fatigue resistance of the reinforcement [18]. With the accumulation of corrosion products, the corrosion-induced cracking of concrete cover occurs, which also accelerates the transport of aggressive agents and the reinforcing bar corrosion rate [19]. The fatigue damage caused by repeated loading accelerates the process of concrete carbonation and reinforcing bar corrosion, and corrosion decreases the fatigue resistance of the reinforcing bar. Therefore, the coupled corrosion-fatigue is more serious than the separate effect or the simple superposition of the corrosion and fatigue, and the coupled effect will lead to a serious reduction of the service life of RC structures [20,21]. Accordingly, it is important to investigate the corrosion-fatigue life of RC structures under coupled carbonation and repeated loading to ensure their service safety.

The performance degradation of RC structures under carbonation [22-25] or fatigue [26-28] has been widely studied. The research related to the deterioration of RC structures under the combined action of carbonation and fatigue has mainly focused on the fatigue performance of corroded RC structures [29,30] and the carbonation of fatigue damaged concrete [31,32]. To date, there have been some studies related to the corrosionfatigue life prediction of RC structures, but they have mainly focused on RC structures with artificial accelerated corrosion or chloride-induced corrosion. Zhang et al. [33] proposed a piecewise linear model to predict the fatigue life of corroded RC beams. Verma and Mishra [34] established a calculation method for corrosion-fatigue life prediction of RC beams based on fracture mechanics and proposed a simplified numerical method to estimate the corrosion-fatigue life. Bastidas et al. [35] presented a novel corrosion-fatigue life assessment model for RC structures in a chloride environment and applied the proposed model to the corrosion-fatigue life assessment of a RC bridge. Wu et al. [36] established a fatigue life prediction model for RC beams under the combined action of chloride-induced corrosion and fatigue based on Fick's second law and Paris' law. Ge and Kim [37] presented a probabilistic method to update the predicted service life of deteriorated RC structures under the coupled process of corrosion and fatigue. Song et al. [38] proposed a corrosionfatigue life assessment model for railway bridges under the combined carbonation-induced corrosion and train loads, but the model did not consider the impact of fatigue damage on concrete carbonation.

In view of the scarce studies that have predicted the service life of RC structures under coupled carbonation and repeated loading, the current research presents a novel corrosionfatigue life prediction model for RC structures under coupled carbonation and repeated loading. The effect of repeated loading on concrete carbonation and carbonation-induced corrosion rate was considered, and the acceleration of fatigue damage accumulation due to reinforcement corrosion was considered in this approach. To illustrate the proposed model, a 6 m-span RC slab in a simply supported slab bridge for the highway was studied. The fatigue damage evolution behavior was obtained, and the corrosion-fatigue life was predicted. The influences of key variables, including traffic frequency, overloading, carbonation environment grade, and environmental temperature and relative humidity, were 
discussed through a parametric analysis. The research is expected to provide a framework for the corrosion-fatigue life prediction of RC structures.

\section{Corrosion-Fatigue Life Prediction Modeling}

\subsection{Concrete Carbonation}

$\mathrm{CO}_{2}$ transport in fatigue-damaged concrete is accommodated by the gas transfer between pores and cracks. Considering the adsorption and reaction rate of $\mathrm{CO}_{2}$ in concrete, the $\mathrm{CO}_{2}$ transport in concrete can be expressed as [39]:

$$
\frac{\partial}{\partial t}\left(\varphi(1-s) C_{\mathrm{CO}_{2}}\right)=\frac{\partial}{\partial x}\left(D_{\mathrm{CO}_{2}} \frac{\partial C_{\mathrm{CO}_{2}}}{\partial x}\right)-Q
$$

where $x$ is the $\mathrm{CO}_{2}$ transport distance in concrete at service time $t, \mathrm{C}_{\mathrm{CO}_{2}}$ is the $\mathrm{CO}_{2}$ concentration around the concrete surface $\left(\mathrm{kg} / \mathrm{m}^{3}\right), \mathrm{D}_{\mathrm{CO}_{2}}$ is the $\mathrm{CO}_{2}$ diffusion coefficient in concrete $\left(\mathrm{m}^{2} / \mathrm{s}\right), \varphi$ is the porosity of the fatigue damaged concrete, $s$ is the pore saturation of concrete, and $Q$ is the total consumption rate of the concrete carbonation.

The amount of $\mathrm{CO}_{2}$ transport in fatigue-damaged RC structures includes the $\mathrm{CO}_{2}$ transport in cracks and damaged but uncracked concrete. The diffusion coefficient can be expressed as [15]:

$$
D_{\mathrm{CO}_{2}}=D_{\mathrm{p}}+\frac{w_{\mathrm{m}}}{l_{\mathrm{m}}} D_{\mathrm{c}}
$$

where $D_{\mathrm{p}}$ is the $\mathrm{CO}_{2}$ diffusion coefficient in damaged but uncracked concrete, $D_{\mathrm{c}}$ is the $\mathrm{CO}_{2}$ diffusion coefficient in concrete cracks, and $w_{\mathrm{m}}$ and $l_{\mathrm{m}}$ are the average crack width and spacing of RC members under repeated loading, respectively.

$\mathrm{CO}_{2}$ transport in concrete is related to the environment temperature [40], humidity [41], and pore structure [15]. $D_{\mathrm{p}}$ can be expressed as:

$$
D_{\mathrm{p}}=1.64 \times 10^{-6} \varphi^{1.8}(1-R H)^{2.2} \exp \left[\frac{U}{R}\left(\frac{1}{T_{0}}-\frac{1}{T_{\mathrm{a}}}\right)\right] p^{2.8}
$$

where $R H$ is the environmental relative humidity, $U$ is the activation energy of carbon dioxide gas, $R$ is the universal gas constant, $T_{0}$ is the standard temperature of the natural environment $(298.15 \mathrm{~K}), T_{\mathrm{a}}$ is the environmental absolute temperature $(\mathrm{K})$, and $p$ is the factor related to fatigue damage, which can be obtained via regression of experimental data in our previous work and is expressed as follows [15]:

$$
p=1+0.311 D_{\mathrm{b}}
$$

where $D_{\mathrm{b}}$ is the damage degree of RC members $\left(0 \leq D_{\mathrm{b}} \leq 1\right)$.

Jiang et al. [32] indicated the $\mathrm{CO}_{2}$ diffusion coefficient in concrete cracks, which can be calculated as:

$$
D_{\mathrm{c}}=(1-\delta) D_{\mathrm{air}}+\delta D_{\mathrm{agg}}
$$

where $\delta$ is the area fraction of aggregates in the concrete crack, and $D_{\text {air }}$ and $D_{\text {agg }}$ are the $\mathrm{CO}_{2}$ diffusion coefficients in air and aggregates, respectively.

The test results indicate that the repeated loading slightly affects the primary crack spacing. Therefore, it can be assumed that the average crack spacing of the RC members remains constant during the repeated loading process and can be computed as [42]:

$$
l_{\mathrm{m}}=\xi\left(1.9 c+0.08 d_{\mathrm{eq}} / \rho_{\mathrm{te}}\right)
$$

where $\xi$ is the influence coefficient of the average crack spacing under repeated loading, $c$ is the thickness of concrete cover $(\mathrm{mm}), d_{\mathrm{eq}}$ is the equivalent diameter of the reinforcements under tension $(\mathrm{mm})$, and $\rho_{\text {te }}$ is the reinforcement ratio of the tensile reinforcements. 
Based on the fatigue test results, the concrete crack width of a RC member under repeated loading is given by [15]:

$$
w_{\mathrm{m}}=\left(0.891+0.1123 \ln n_{\mathrm{f}}\right) w_{0}
$$

where $w_{0}$ is the average initial crack width of the RC members and $n_{\mathrm{f}}$ is the number of repeated loading cycles.

The known experimental studies have shown that the carbonation process of fatiguedamaged concrete can be calculated by Fick's first law [31]. Consequently, the carbonation depth $X$ of the concrete at service time $t$ can be calculated as:

$$
X=K \sqrt{t}
$$

where $K$ is the carbonation coefficient. Papadakis et al. [43] proposed a theoretical model for concrete carbonation through the mass-balance condition of the carbonatable substance, which can be expressed as:

$$
X=\sqrt{\frac{2 D_{\mathrm{CO}_{2}} C_{\mathrm{CO}_{2}}}{\left[\mathrm{Ca}(\mathrm{OH})_{2}\right]^{0}+3[\mathrm{CSH}]^{0}+3\left[\mathrm{C}_{3} \mathrm{~S}\right]^{0}+2\left[\mathrm{C}_{2} \mathrm{~S}\right]^{0}}} \sqrt{t}
$$

where $\left[\mathrm{Ca}(\mathrm{OH})_{2}\right]^{0},[\mathrm{CSH}]^{0},\left[\mathrm{C}_{3} \mathrm{~S}\right]^{0}$, and $\left[\mathrm{C}_{2} \mathrm{H}\right]^{0}$ are the carbonatable substance densities in the concrete.

\subsection{Carbonation-Induced Reinforcing Bar Corrosion}

Carbonation-induced reinforcing bar corrosion is usually considered uniform (general) corrosion [44]. For the uniform corrosion model, the cross-sectional loss area ratio of reinforcement $\varepsilon(t)$ (i.e., cross-sectional corrosion ratio) can be computed as:

$$
\varepsilon(t)=\frac{\Delta A_{\mathrm{s}}}{A_{\mathrm{s}}}=\frac{4 a(t)}{d_{0}}-\frac{4 a^{2}(t)}{d_{0}^{2}}
$$

where $A_{\mathrm{s}}$ is the initial cross-sectional area of the reinforcing bar $\left(\mathrm{mm}^{2}\right), \Delta A_{\mathrm{s}}$ is the crosssectional loss area of the reinforcing bar caused by uniform corrosion $\left(\mathrm{mm}^{2}\right), a(t)$ is the reinforcement corrosion depth $(\mathrm{mm})$, and $d_{0}$ is the initial diameter of reinforcement $(\mathrm{mm})$. The uniform corrosion form of the reinforcing bar is shown in Figure 1.

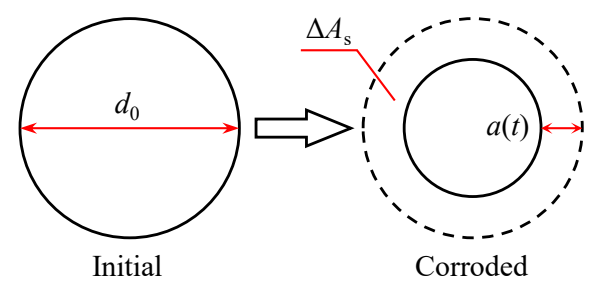

Figure 1. Uniform corrosion of the reinforcing bar.

The Chinese code GB/T 51355-2019 [45] suggests a method for carbonation-induced reinforcing bar corrosion. When reinforcing bar corrosion initiates, a certain depth of concrete cover free of carbonation still exists, which can be defined as carbonation remaining depth $X_{0}$. The carbonation remaining depth $X_{0}$ can be estimated by:

$$
X_{0}=\left(1.2-0.35 K^{0.5}\right) D_{\mathrm{k}}-\frac{6}{m_{\mathrm{ef}}+1.6}(1.5+0.84 K)
$$

where $m_{\mathrm{ef}}$ is the carbonation environmental factor; $D_{\mathrm{k}}$ is the factor associated with both $c$ and $K$. The carbonation environment factor $m_{\mathrm{ef}}$ can be determined by carbonation environmental aggressiveness, including the four grades A, B, C, and D (Table 1). 
Table 1. Description of the carbonation environment grades.

\begin{tabular}{ccc}
\hline $\begin{array}{c}\text { Grade of Carbonation } \\
\text { Environment }\end{array}$ & Description & $m_{\mathbf{e f}}$ \\
\hline A & $\begin{array}{c}\text { A general indoor environment or a } \\
\text { general outdoor environment } \\
\text { without rain and pollution. } \\
\text { An indoor humid environment, an } \\
\text { indoor dry and wet alternative } \\
\text { environment, or a slightly polluted } \\
\text { environment without rain. } \\
\text { An outdoor rain environment, an } \\
\text { acid rain environment, a general } \\
\text { freezing-thawing environment, or a } \\
\text { heavily polluted environment. } \\
\text { An outdoor rain environment in a } \\
\text { humid and hot area. }\end{array}$ & $1.0-1.2$ \\
& & \\
D & $2.5-4.0$ \\
\hline
\end{tabular}

For the factor $D_{\mathrm{k}}$, when $c \leq 28 \mathrm{~mm}$,

$$
D_{\mathrm{k}}= \begin{cases}c-0.16 / K, & K<0.8 \\ c, & K \geq 0.8\end{cases}
$$

When $c>28 \mathrm{~mm}$,

$$
D_{\mathrm{k}}= \begin{cases}c-0.389(c-28)(0.16 / K)^{1.5}, & K<1.0 \\ c+0.066(c-28)^{0.47 K}, & 1.0 \leq K<3.3 \\ c+0.066(c-28)^{1.55}, & K \geq 3.3\end{cases}
$$

When reinforcing bar corrosion initiates, the corrosion initiation time $t_{\text {ini }}$ can be calculated as:

$$
t_{\text {ini }}=\left(\frac{c-X_{0}}{K}\right)^{2}
$$

The reinforcing bar corrosion rate before concrete cracking can be computed by:

$$
i_{\text {ini }}=7.53 K_{\mathrm{cl}} m_{\mathrm{ef}}(0.75+0.0125 T)(R H-0.45)^{2 / 3} c^{-0.675} f_{\mathrm{cu}}^{-1.8}
$$

where $K_{\mathrm{cl}}$ is the reinforcement location factor, $K_{\mathrm{cl}}$ is equal to 1.6 at the corner of RC members and 1.0 at other locations, $T$ is the environmental temperature $\left({ }^{\circ} \mathrm{C}\right)$, and $f_{\mathrm{cu}}$ is the concrete cubic compressive strength (MPa).

With the increase of corrosion degree, the concrete cover will crack (corrosion-induced cracking). When the concrete cracks due to corrosion, the reinforcement corrosion depth can be estimated as:

$$
a_{\mathrm{cr}, \mathrm{c}}=0.012 c / d_{0}+0.00084 f_{\mathrm{cu}}+0.018
$$

The time to corrosion-induced cracking can be calculated as:

$$
t_{\mathrm{cr}, \mathrm{c}}=a_{\mathrm{cr}, \mathrm{c}} / i_{\mathrm{ini}}+t_{\mathrm{ini}}
$$

Concrete will also crack when the RC members are subjected to repeated loading. $\mathrm{Li}$ [46] proposed the S-N curve of concrete cracking due to repeated loading, which can be represented as:

$$
f_{\mathrm{t}}^{\max } / f_{\mathrm{t}}=1.3681-0.1214 \lg N_{\mathrm{cr}}
$$

where $f_{\mathrm{t}}^{\max }$ is the maximum tensile stress of the concrete under constant amplitude repeated loading $(\mathrm{MPa}), f_{\mathrm{t}}$ is the concrete tensile strength $(\mathrm{MPa})$, and $N_{\mathrm{cr}}$ is the number of loading cycles when concrete cracks due to fatigue. 
When using the S-N curve for concrete cracking prediction, fatigue damage in concrete under tension caused by repeated loading is accumulated according to Miner's rule [47]:

$$
D_{\mathrm{cr}}=\sum_{i=1} \frac{n_{\mathrm{cr}, i}}{N_{\mathrm{cr}, i}}=\sum_{i=1} 10^{\frac{f_{\mathrm{t}, i}^{\max } / f_{\mathrm{t}}-1.3681}{0.1214}} \cdot n_{\mathrm{cr}, i}
$$

where $D_{\mathrm{cr}}$ is the fatigue damage of tensile concrete caused by repeated loading, $D_{\mathrm{cr}} \geq 1$ indicates the concrete cracking, $n_{\mathrm{cr}, i}$ is the number of concrete tensile stress cycles with the $i$-th maximum tensile stress $f_{\mathrm{t}, i}^{\max }$, and $N_{\mathrm{cr}, i}$ is the number of concrete tensile stress cycles when concrete cracks due to fatigue under the $i$-th maximum tensile stress $f_{\mathrm{t}, i}$ max .

Under the constant amplitude repeated loading, the fatigue-induced cracking time of concrete cover can be obtained:

$$
t_{\mathrm{cr}, \mathrm{t}}=10^{\frac{1.3681-f_{\mathrm{t}}^{\max } / f_{\mathrm{t}}}{0.1214}} / f
$$

where $f$ is the loading frequency of each period. For variable amplitude repeated loading, Song et al. [38] showed the calculation method for equivalent maximum tensile stress.

The concrete cracking time $t_{\mathrm{cr}}$ is the smaller value of corrosion-induced cracking time $t_{\mathrm{cr}, \mathrm{c}}$ and fatigue-induced cracking time $t_{\mathrm{cr}, \mathrm{f}}$. Thus, the concrete cracking time $t_{\mathrm{cr}}$ can be calculated as:

$$
t_{\mathrm{cr}}=\min \left\{t_{\mathrm{cr}, \mathrm{c}}, t_{\mathrm{cr}, \mathrm{f}}\right\}
$$

When fatigue-induced concrete cracking occurs, the reinforcement corrosion depth $a_{\mathrm{cr}, \mathrm{f}}$ can be computed as:

$$
a_{\mathrm{cr}, \mathrm{f}}= \begin{cases}0 & t_{\mathrm{cr}, \mathrm{f}} \leq t_{\text {ini }} \\ i_{\text {ini }}\left(t_{\mathrm{cr}, \mathrm{f}}-t_{\mathrm{ini}}\right) & t_{\mathrm{cr}, \mathrm{f}}>t_{\text {ini }}\end{cases}
$$

When concrete cracking begins, the corrosion depth $a_{\mathrm{cr}}$ can be expressed as:

$$
a_{\mathrm{cr}}=\min \left\{a_{\mathrm{cr}, \mathrm{c}}, a_{\mathrm{cr}, \mathrm{f}}\right\}
$$

Because concrete cracks will accelerate reinforcing bar corrosion, the corrosion rate after concrete cracking can be estimated by:

$$
i_{\mathrm{cr}}=\left(4.5-340 i_{\text {ini }}\right) i_{\text {ini }}
$$

According to the above models, the reinforcing bar corrosion depth can be calculated as:

$$
a(t)= \begin{cases}0, & t<t_{\text {ini }} \\ i_{\text {ini }}\left(t-t_{\text {ini }}\right), & t_{\text {ini }}<t \leq t_{\mathrm{cr}} \\ a_{\mathrm{cr}}+i_{\mathrm{cr}}\left(t-t_{\mathrm{cr}}\right), & t>t_{\mathrm{cr}}\end{cases}
$$

\subsection{Corrosion-Fatigue Life Prediction}

The corrosion-fatigue failure mode of RC structures or members is generally the brittle fracture of reinforcing bars under the coupled corrosion and fatigue [48]. The S-N curve describes the fatigue resistance of materials, and the S-N curve of reinforcing bars can be expressed as:

$$
\lg N=\lg C-m \lg (\Delta \sigma)
$$

where $\Delta \sigma$ is the stress range of reinforcing bars $(\mathrm{MPa}), N$ is the number of stress cycles at reinforcement fatigue fracture under the stress range $\Delta \sigma$, and $C$ and $m$ are the material coefficients for the reinforcing bars. 
Fatigue damage accumulation in the reinforcing bar caused by repeated loading is also calculated by Miner's rule, which can be determined as [47]:

$$
D_{\mathrm{t}}=\sum_{i=1} \frac{n_{i}}{N_{i}}=\frac{1}{C} \sum_{i=1} n_{i}\left(\Delta \sigma_{i}\right)^{m}
$$

where $D_{\mathrm{t}}$ is the cumulative fatigue damage in the reinforcing bar, and $D_{\mathrm{t}} \geq 1$ indicates the reinforcing bar rupture; $n_{i}$ is the number of reinforcing bar stress cycles with the $i$-th stress range $\Delta \sigma_{i} ;$ and $N_{i}$ is the number of reinforcing bar stress cycles when the reinforcing bar fatigue ruptures under the $i$-th stress range $\Delta \sigma_{i}$. For variable amplitude repeated loading, $\mathrm{Li}$ et al. [49] showed the calculation method for equivalent stress range.

As the corrosion degree increases, the fatigue stress ranges increase, and the fatigue resistance decreases [10]. Considering the time-variant of fatigue stress range and fatigue resistance, Equation (26) can be rewritten as follows:

$$
\lg N=\lg C(t)-m \lg (\Delta \sigma(t))
$$

The time-variant effect of material coefficient $C$ can be represented by:

$$
C(t)=C_{0} \phi(t)
$$

where $C_{0}$ is the initial value material coefficient $C$ of the reinforcing bar without corrosion. $\phi(t)$ can be calculated as [50]:

$$
\phi(t)= \begin{cases}1, & a(t)<1.3428 \mathrm{~mm} \\ -0.79 a(t)^{2}+1.88 a(t)-0.1, & 1.34 \mathrm{~mm} \leq a(t) \leq 2.3353 \mathrm{~mm} \\ 0, & a(t) \geq 2.3353 \mathrm{~mm}\end{cases}
$$

The time-variant reinforcement stress range can be calculated as:

$$
\Delta \sigma(t)=\Delta \sigma_{0} /(1-\varepsilon(t))
$$

where $\Delta \sigma_{0}$ is the reinforcement stress range without corrosion under repeated loading (MPa).

When the RC structure is in service until the $J$-th period, the cumulative fatigue damage of reinforcement $D_{\mathrm{t}}$ can be calculated as:

$$
D_{\mathbf{t}}=\sum_{j=1}^{J} \sum_{i=1} \frac{\left(\Delta \sigma_{i}(t)\right)^{m} f_{i, j}}{C(t)}
$$

where $f_{i, j}$ is the loading frequency of the $i$-th stress range $\Delta \sigma_{i}$ in the $j$-th period. When $D_{\mathrm{t}}$ reaches 1 , fatigue failure will occur, and the fatigue life $t_{\mathrm{r}}$ can be obtained.

\subsection{Corrosion-Fatigue Life Prediction Flowchart}

The above models are applied to the corrosion-fatigue life prediction of RC structures under coupled carbonation and repeated loading. A computational program for the corrosion-fatigue life prediction was developed in the MATLAB environment (version 2016a, The Mathworks, Natick, MA, USA) following the steps outlined in Figure 2. The additional details can be summarized as follows:

(1) Input the structural parameters, load parameters, material behavior, and environmental factors. Then, calculate the reinforcement and concrete stress cycles due to repeated loading.

(2) Determine the $\mathrm{CO}_{2}$ transport in fatigue damaged process through Equations (1)-(7).

(3) Obtain the carbonation process of fatigue-damaged concrete through Equations (8) and (9).

(4) Estimate the reinforcement corrosion initiation time and the corrosion rate before concrete cracking through Equations (11)-(15). 
(5) Compute the concrete cracking time and the corrosion rate after concrete cracking through Equations (16)-(24).

(6) Calculate the reinforcement corrosion depth and corrosion ratio through Equations (10) and (25).

(7) Obtain the fatigue resistance and fatigue damage of uncorroded reinforcement through Equations (26) and (27).

(8) Determine the fatigue resistance decrease behavior through Equations (28)-(31).

(9) Calculate the cumulative fatigue damage $D_{t}$ through Equation (32),

(10) Output the corrosion-fatigue life by judging whether $D_{t}$ reaches 1.

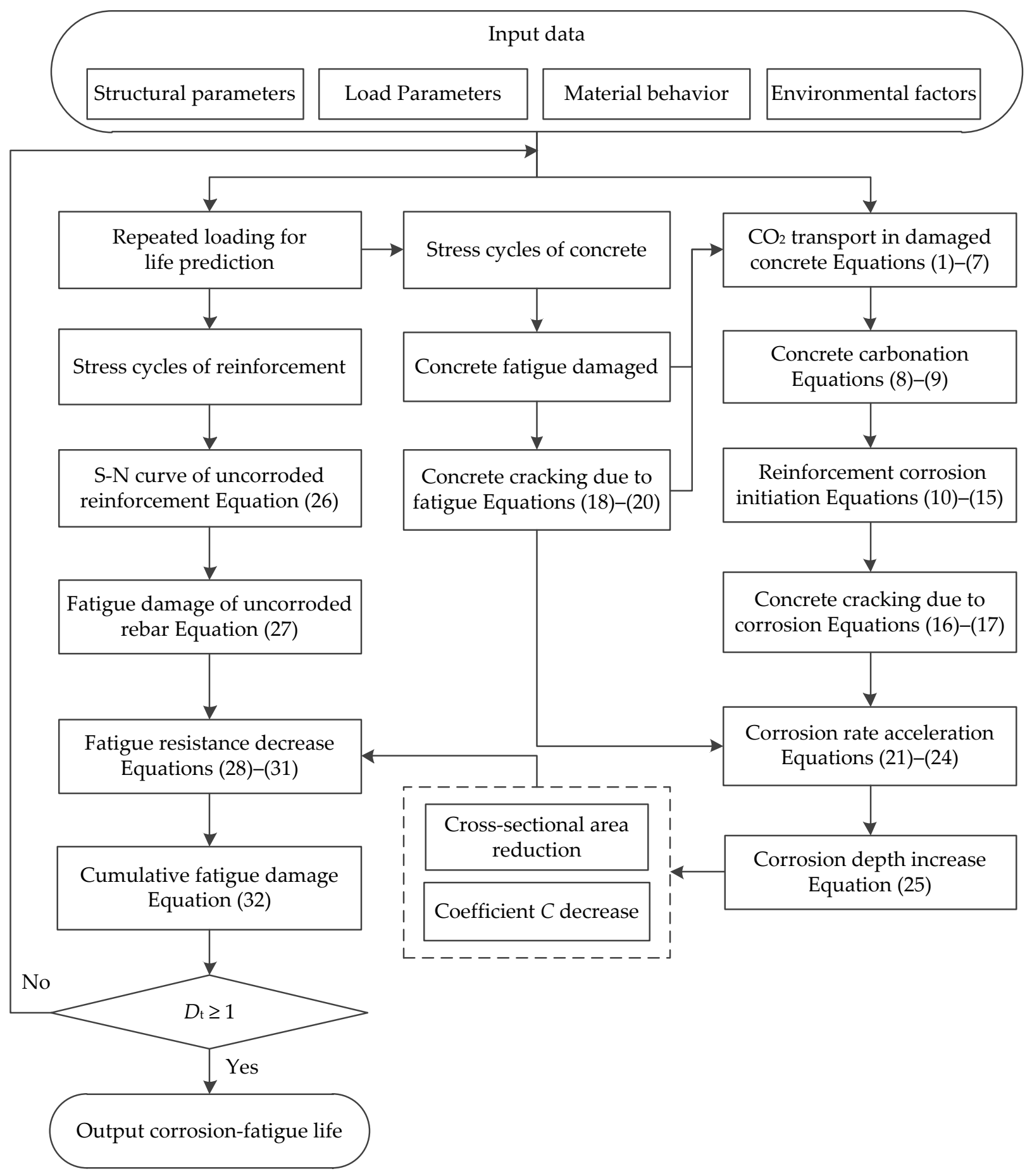

Figure 2. Corrosion-fatigue life prediction process for RC structures. 


\section{Model Application}

To illustrate the corrosion-fatigue life prediction model of RC structures under the coupled carbonation and repeated loading, the fatigue damage and corrosion-fatigue life of an RC slab in a highway RC simply supported slab bridge were evaluated. The span of the analyzed RC slab was $6 \mathrm{~m}$, with a height of $0.32 \mathrm{~m}$ and a width of $0.91 \mathrm{~m}$. The concrete strength grade of the slab was C30 (150 mm cubic compressive strength of $30 \mathrm{MPa}$ at age of 28 days). Tensile reinforcement with a diameter of $18 \mathrm{~mm}$ was configured at the bottom of the slab, and the reinforcement strength grade was HRB335 (hot-rolled ribbed steel bar with a yield strength standard value of $335 \mathrm{MPa}$ ). The other reinforcements were $10 \mathrm{~mm}$ in diameter and HPB300 (hot-rolled plain steel bar with a yield strength standard value of $300 \mathrm{MPa}$ ) in strength grade. The geometric dimensions and reinforcement of the mid-span cross-section of the RC slab are shown in Figure 3. The design service life of the $6 \mathrm{~m}$-span $\mathrm{RC}$ slab is 100 years. The thickness of the concrete cover is $50 \mathrm{~mm}$, and the carbonation environment grade of the bridge is $\mathrm{B}$. The annual average environmental temperature and relative humidity at the location of the slab bridge are $15^{\circ} \mathrm{C}$ and $65 \%$, respectively. Table 2 lists the material properties and environmental factors used in the corrosion-fatigue life prediction.

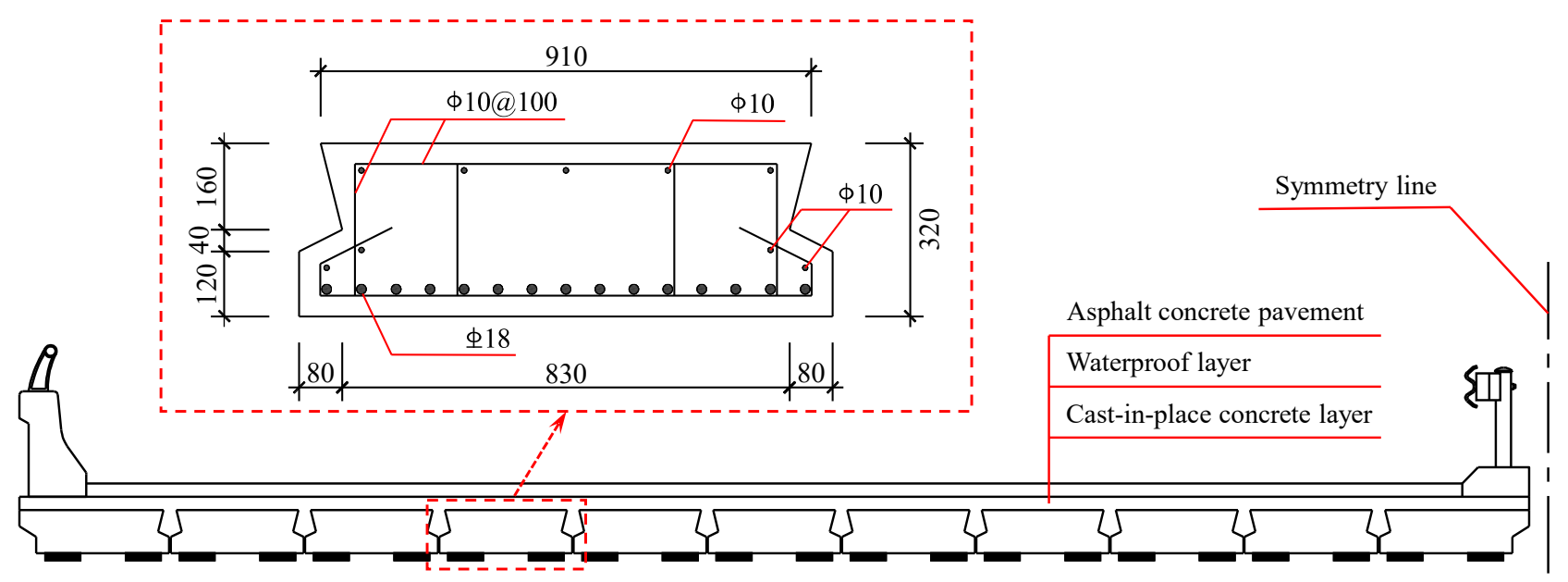

Figure 3. Details of the $6 \mathrm{~m}$-span simply supported RC slab bridge.

Table 2. Parameter values of the $6 \mathrm{~m}$-span RC slab.

\begin{tabular}{ccc}
\hline Parameter & Value & Description \\
\hline$f_{\mathrm{cu}}$ & $30 \mathrm{MPa}$ & Cubic compressive strength of concrete \\
$f_{\mathrm{c}}$ & $20.1 \mathrm{MPa}$ & Compressive strength of concrete \\
$f_{\mathrm{t}}$ & $1.43 \mathrm{MPa}$ & Tensile strength of concrete \\
$E_{\mathrm{c}}$ & $3 \times 10^{4} \mathrm{MPa}$ & Elastic modulus of concrete \\
$v_{\mathrm{c}}$ & 0.2 & Poisson's ratio of concrete \\
$f_{\mathrm{y}}$ & $335 \mathrm{MPa}$ & Yield strength of tensile reinforcement \\
$E_{\mathrm{s}}$ & $2 \times 10^{5} \mathrm{MPa}$ & Elastic modulus of tensile reinforcement \\
$d_{0}$ & $18 \mathrm{~mm}$ & Diameter of tensile reinforcement \\
$c$ & $50 \mathrm{~mm}$ & Thickness of concrete cover \\
$\gamma$ & $25 \mathrm{kN} / \mathrm{m}^{3}$ & Weight of reinforced concrete \\
$m_{\mathrm{ef}}$ & 2.5 & B-grade carbonation environment factor \\
$T$ & $15{ }^{\circ} \mathrm{C}$ & Environmental temperature \\
$R H$ & $65 \%$ & Environmental relative humidity \\
\hline
\end{tabular}

Because the small car only has a slight influence on the fatigue performance of the bridge, to simplify the analysis, only the influences of heavy vehicles on corrosion-fatigue life are considered in this paper. Under the dead load, secondary dead load, and vehicle load, the design values of the mid-span bending moment of the RC slab are $43.33 \mathrm{kN} \cdot \mathrm{m}$, 
$16.25 \mathrm{kN} \cdot \mathrm{m}$, and $132.69 \mathrm{kN} \cdot \mathrm{m}$, respectively. Therefore, the mid-span bending moment caused by the maximum and minimum of repeated loading acting on the RC slab is $59.58 \mathrm{kN} \cdot \mathrm{m}$ and $192.27 \mathrm{kN} \cdot \mathrm{m}$, respectively. The design value of traffic frequency $f$ of heavy vehicles on the highway is 1000/day. For highway RC bridges, it is necessary to obtain the stress response of tensile reinforcement under repeated vehicle loads when predicting the corrosion-fatigue life. Because the RC slab is a flexural member, the tensile reinforcement stress of the mid-span cross-section can be calculated as:

$$
\sigma_{\mathrm{s}}=n_{\mathrm{s}} \frac{M y}{I}
$$

where $n_{\mathrm{S}}$ is the ratio of elastic modulus of tensile reinforcement to concrete, $M$ is the bending moment at the mid-span of the slab, $y$ is the distance from the position of tensile reinforcement to the neutral axis of the mid-span transfer section, and $I$ is the inertia moment of the mid-span transfer section. For the $6 \mathrm{~m}$-span RC slab, $y=0.0989 \mathrm{~m}$, $I=2.8230 \times 10^{-3} \mathrm{~m}^{4}$; and $y=0.1345 \mathrm{~m}, I=1.3153 \times 10^{-3} \mathrm{~m}^{4}$ after the concrete cover cracking. Under repeated vehicle loading, the maximum and minimum of the stress cycles in tensile reinforcements are $40.61 \mathrm{MPa}$ and $131.06 \mathrm{MPa}$, respectively, and the stress range of the tensile reinforcements is $90.45 \mathrm{MPa}$.

The selection of the S-N curve is very important to the corrosion-fatigue life prediction results. Eurocode [51] presents the S-N curve for reinforcing bars in RC structures, which can be expressed as:

$$
\begin{cases}\log N=17.0543-5 \log \Delta \sigma, & N \leq 10^{6} \\ \log N=25.8977-9 \log \Delta \sigma, & \quad N>10^{6}\end{cases}
$$

\section{Results and Discussion}

\subsection{Corrosion-Fatigue Life Prediction}

The fatigue damage of tensile reinforcing bar with different corrosion ratios caused by a heavy vehicle passage is shown in Figure 4 . When the corrosion ratio of reinforcement is $0 \%, 10 \%, 20 \%, 30 \%$, and $40 \%$, the corrosion depth is $0 \mathrm{~mm}, 0.462 \mathrm{~mm}, 0.950 \mathrm{~mm}, 1.470 \mathrm{~mm}$, and $2.029 \mathrm{~mm}$, respectively, and the corresponding fatigue damage caused by a heavy vehicle passage is $5.13 \times 10^{-9}, 1.32 \times 10^{-8}, 3.82 \times 10^{-8}, 1.33 \times 10^{-7}$, and $1.10 \times 10^{-6}$, respectively. With the increase of corrosion ratio, the fatigue damage caused by a heavy vehicle passage increases significantly.

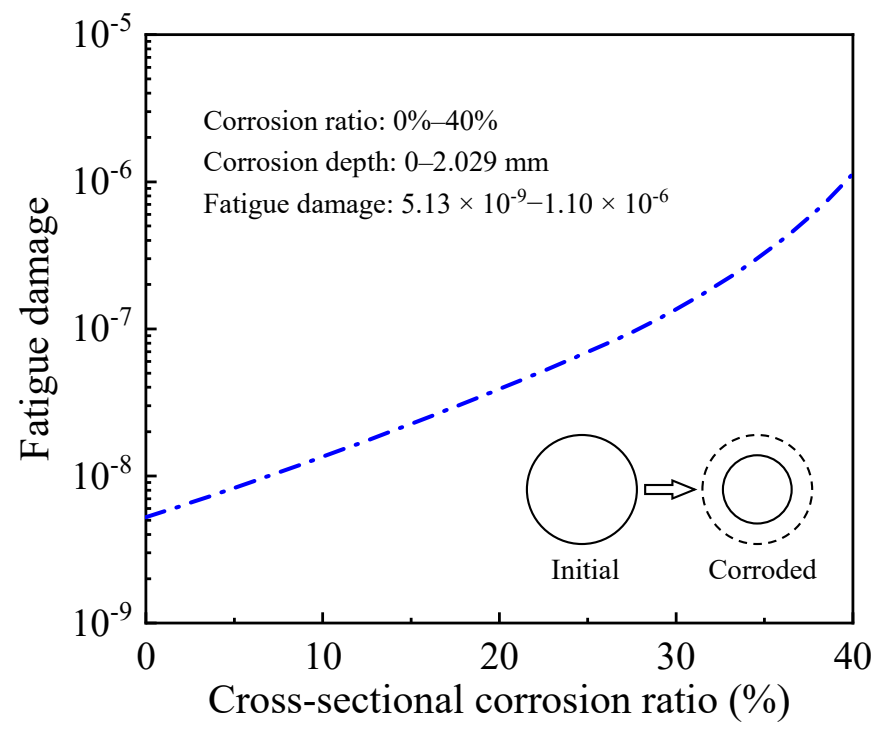

Figure 4. Fatigue damage caused by a heavy vehicle passage. 
The repeated loading frequency is the design traffic frequency of heavy vehicles (1000/day). Under a B-grade carbonation environment, the cumulative fatigue damage of tensile reinforcement in the $6 \mathrm{~m}$-span RC slab is shown in Figure 5. Under the design service condition, the corrosion-fatigue performance of the RC slab is satisfactory. When the bridge is operated to the design service life, the cumulative fatigue damage in the tensile reinforcement in the slab is 0.372 . With the deepening of reinforcement corrosion and the accelerating of fatigue damage accumulation, the corrosion-fatigue failure of the RC slab will occur, and the corrosion-fatigue life of the RC slab is 162.1 years.

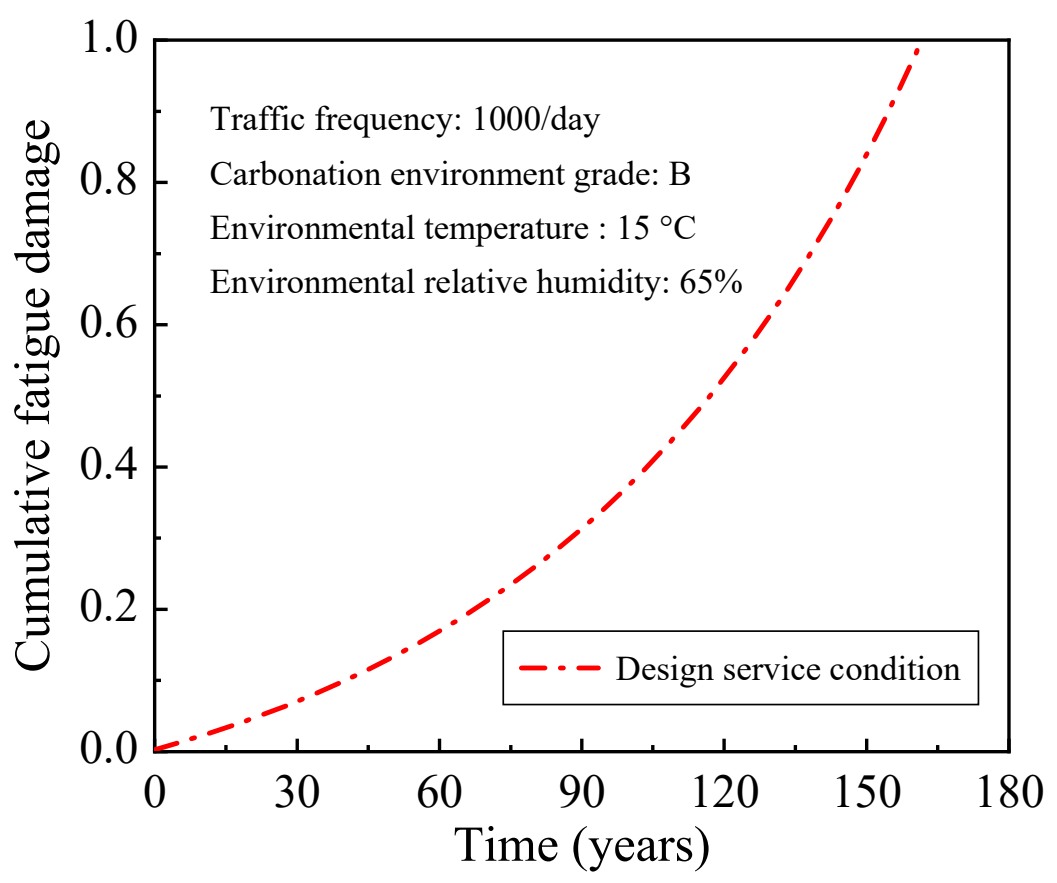

Figure 5. Cumulative fatigue damage evolution under the design service condition.

\subsection{Effect of Traffic Frequency and Overloading}

In recent years, the traffic frequency of highways in China has increased significantly, which will cause a detrimental impact on the corrosion-fatigue performance of RC bridges. To study the influence of traffic frequency, the corrosion-fatigue life of the RC slab with traffic frequencies of 500/day, 1000/day, 3000/day, 5000/day, and 7000/day is predicted. These traffic frequencies are defined by the monitoring of a highway bridge in China [52] and the design traffic frequency. To simplify the analysis, the traffic frequencies are considered time-invariant. The carbonation environment grade, environmental temperature, and relative humidity under different cases of traffic frequency are the same as the design service condition in Section 4.1.

Figure 6 illustrates the cumulative fatigue damage evolution of the tensile reinforcement in the $6 \mathrm{~m}$-span RC slab under different cases of traffic frequency. With the increase of traffic frequency, the fatigue damage increases, and fatigue damage accumulation accelerates. When the highway bridge is operated to the design service life, the cumulative fatigue damage of the two cases with traffic frequency of 500/day and 1000/day is 0.186 and 0.372 , respectively. Under the three cases with traffic frequency 3000/day, 5000/day, and 7000/day, the cumulative fatigue damage reaches the limit value in the 95th, 70th, and 54th years of bridge operation, and corrosion-fatigue failure of RC slab occurs. Under these three cases, the corrosion-fatigue life of the $6 \mathrm{~m}$-span RC slab under the coupled carbonation and repeated vehicle load cannot reach the expected design service life. Therefore, it is necessary to strengthen the maintenance and repair of the bridge. 


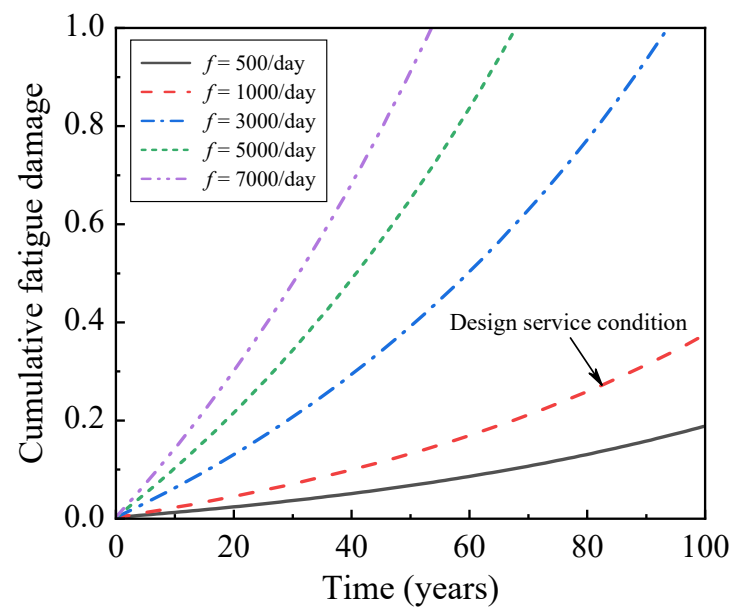

Figure 6. Cumulative fatigue damage evolution with different traffic frequency cases.

Overloading may occur with the increase of highway traffic volume. Previous research results have shown that overloading will substantially reduce the corrosion-fatigue life of bridges [53]. Consequently, it is necessary to investigate the effect of overloading on the corrosion-fatigue life of RC structures. To simplify the analysis, this study considers the overloading condition by increasing the design vehicle load. Four overloading cases with different overloading ratios are considered in this study, increasing the design load by $5 \%$, $10 \%, 15 \%$, and $20 \%$, respectively. The traffic frequency, carbonation environment grade, and environmental temperature and relative humidity of each overloading case are the same as the design service condition in Section 4.1.

Figure 7 plots the cumulative fatigue damage evolution of the tensile reinforcement in the $6 \mathrm{~m}$-span RC slab under different overloading cases. Similarly, with the increase of the overloading ratio, the fatigue damage increases, and fatigue damage accumulation accelerates. When the highway bridge is operated to the design service life, the cumulative fatigue damage of the two cases with overloading ratios of $5 \%$ and $10 \%$ is 0.567 and 0.861 , respectively. Compared with the design service condition without overloading, the fatigue damage of the two cases increases by $55.1 \%$ and $135.8 \%$, respectively. When the overloading ratio is $15 \%$ and $20 \%$, the cumulative fatigue damage reaches the limit value in the 87th and 68th years of bridge operation, and corrosion-fatigue failure of RC slab occurs. An overloading ratio of $20 \%$ will reduce the corrosion-fatigue life of the RC slab significantly. Therefore, overloading must be strictly prohibited during bridge operation.

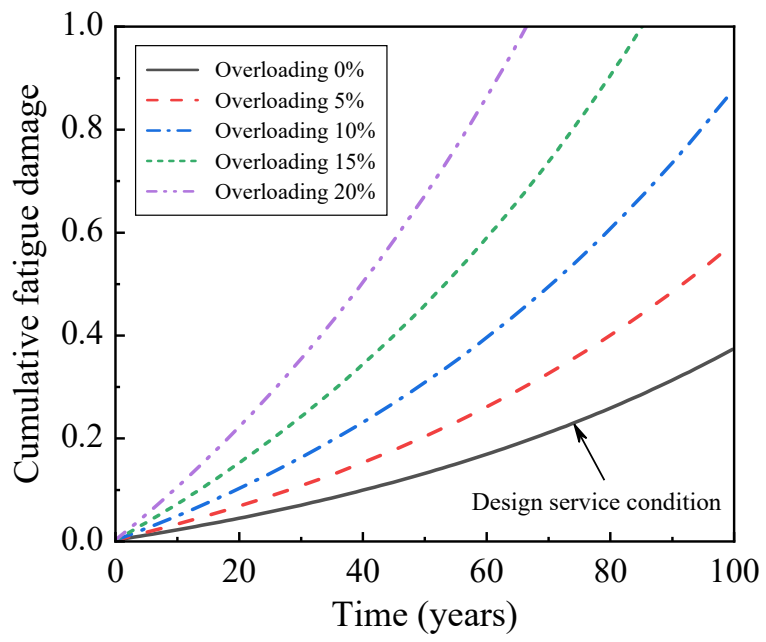

Figure 7. Cumulative fatigue damage evolution with different overloading cases. 
Figure 8 depicts the corrosion-fatigue life of the $6 \mathrm{~m}$-span RC slab under different traffic frequencies and overloading cases. It can be obtained from Figure 8 that the corrosionfatigue life will be substantially reduced as the traffic frequency and overloading ratio increase simultaneously, and the corrosion-fatigue life of the RC slab is 13.5 to 162.1 years under different traffic frequencies and overloading cases. The corrosion-fatigue life is 93.9 years, 68.0 years, and 53.7 years, respectively, under the traffic frequency cases of 3000/day, 5000/day, and 7000/day without overloading. Compared with the design service condition, the corrosion-fatigue life of the three traffic frequency cases decrease by $42.07 \%, 58.02 \%$, and $66.86 \%$, respectively. When the traffic frequency is $1000 /$ day and the overloading ratio is $5 \%, 10 \%, 15 \%$, and $20 \%$, respectively, the corrosion-fatigue life is 133.3 years, 107.6 years, 85.3 years, and 66.6 years, respectively. The four overloading cases will reduce the corrosion-fatigue life by $17.77 \%, 33.61 \%, 47.35 \%$, and $58.90 \%$, respectively, compared with the design service condition.

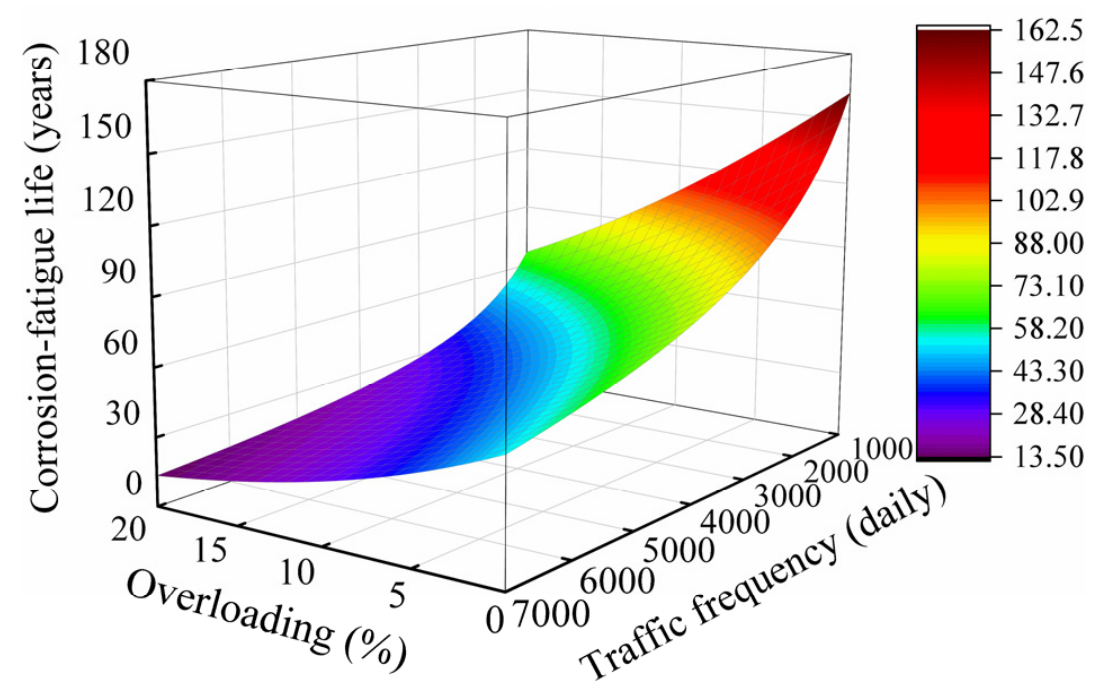

Figure 8. Corrosion-fatigue life with different traffic frequency and overloading cases.

\subsection{Effect of Carbonation Environment Grade}

The carbonation environment grade will affect the concrete carbonation and the corrosion rate of the reinforcing bar, which, in turn, affects the corrosion-fatigue life of $\mathrm{RC}$ structures. To study the effect of carbonation environment grade on corrosion-fatigue life, the cumulative fatigue damage and corrosion-fatigue life of the $6 \mathrm{~m}$-span RC slab under different carbonation environments are evaluated. The environmental temperature and relative humidity are the same as the design service condition. Figure 9 shows the cumulative fatigue damage evolution of the tensile reinforcement in the $6 \mathrm{~m}$-span RC slab under different carbonation environments and different traffic frequencies.

It can be seen from Figure 9 that with the increase of carbonation environment level, the fatigue damage increases, and fatigue damage accumulation accelerates. When the bridge is operated for 100 years with the traffic frequency of 1000/day, the cumulative fatigue damage of tensile reinforcement is $0.187,0.261,0.372,0.483$, and 0.616 , respectively, under five environmental cases of carbonation-free and carbonation environment grades $\mathrm{A}$ to D. Compared with the carbonation-free environment, the fatigue damage increases by $39.31 \%, 98.69 \%, 158.00 \%$, and $229.24 \%$ under the four different carbonation environment grades. As the traffic frequency increases to 7000/day, the corrosion-fatigue failure of the RC slab will occur when the bridge is operated for 77th, 63th, 55th, 55th, and 47th years, respectively, under carbonation-free and carbonation environment grades $\mathrm{A}$ to $\mathrm{D}$. 


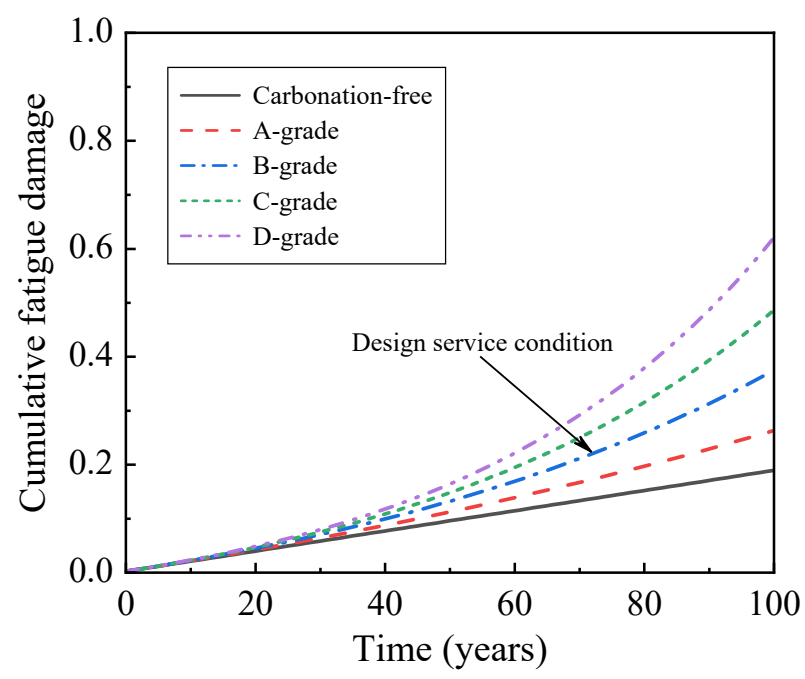

(a)

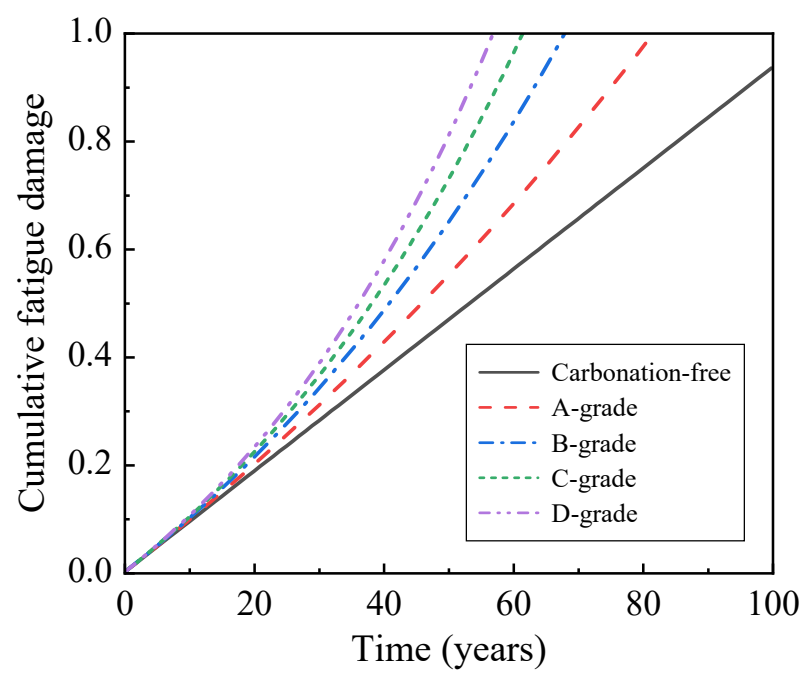

(c)

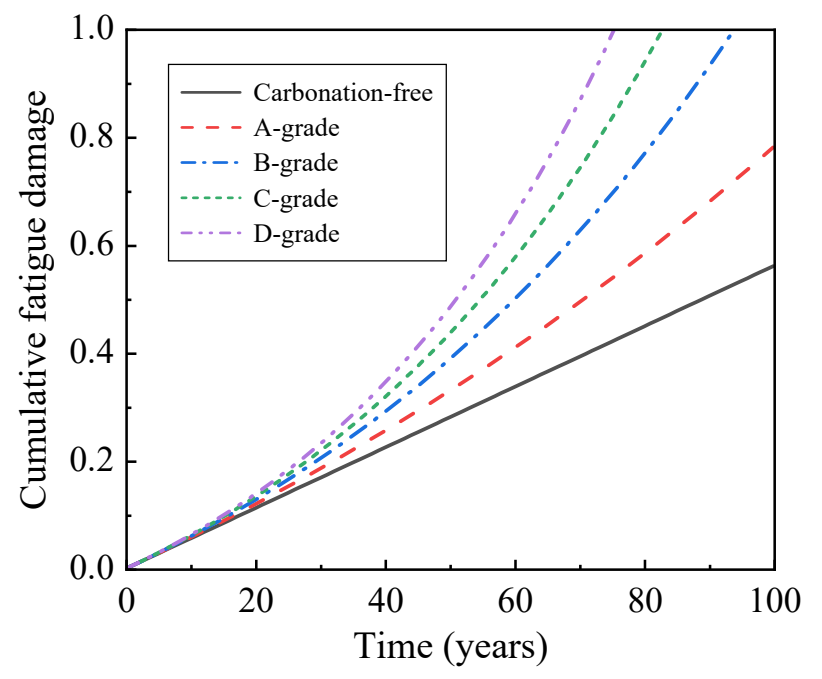

(b)

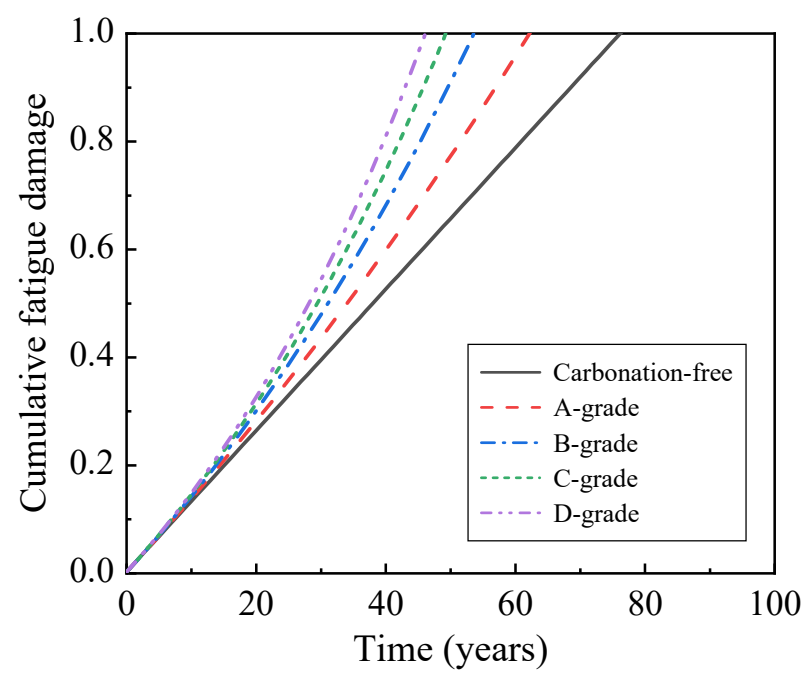

(d)

Figure 9. Cumulative fatigue damage evolution with different carbonation environment grades: (a) $f=1000 /$ day; (b) $f=3000 /$ day; (c) $f=5000 /$ day; and (d) $f=7000 /$ day.

Figure 10 shows the corrosion-fatigue life of $6 \mathrm{~m}$-span RC slab under different carbonation environment grades and different traffic frequencies. A higher carbonation environment grade will cause a shorter corrosion-fatigue life. With the increase of traffic frequency, the effect of carbonization environment grade on corrosion-fatigue life decreases. Similarly, the higher the carbonization environment grade, the lower the influence of traffic frequency on corrosion-fatigue life.

When the traffic frequency is 1000 /day to 7000 /day, the fatigue life is $534.3-76.3$ years under a carbonation-free environment, and the corrosion-fatigue life is 232.5-62.3 years, 162.1-53.7 years, 136.5-49.4 years, and 120.5-46.2 years, respectively, under the carbonation environment grades A to D. When the traffic frequency increases from 1000/day to 7000 / day, the fatigue life decreases by $85.71 \%$ under the carbonation-free environment, and the corrosion-fatigue life decreases by $73.20 \%, 66.86 \%, 63.83 \%$, and $61.66 \%$, respectively, under the carbonation environment grades A to D. Under the traffic frequency of 1000/day to 7000/day, carbonation environment grades A, B, C, and D can decrease the corrosion-fatigue life by $56.48 \%-18.37 \%, 69.67 \%-29.64 \%, 74.46 \%-35.33 \%$, and $77.45 \%-$ $39.48 \%$, respectively, compared with a carbonation-free environment. 


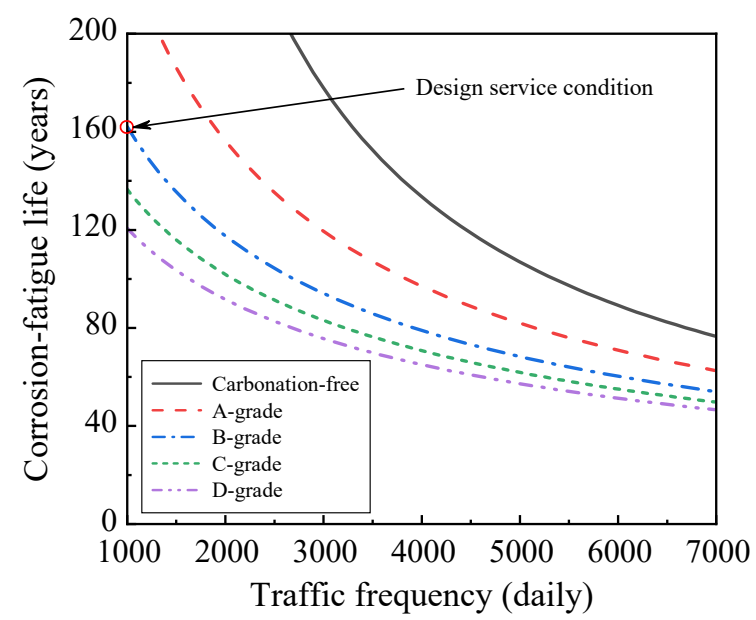

Figure 10. Corrosion-fatigue life under different carbonation environments.

\subsection{Effect of Environmental Temperature and Relative Humidity}

The environmental temperature and relative humidity of the bridge service environment will affect the corrosion-fatigue life of RC structures [54]. Therefore, the corrosionfatigue life of the $6 \mathrm{~m}$-span RC slab under four grades of carbonation environment with various temperatures $\left(5-25{ }^{\circ} \mathrm{C}\right)$ and relative humidity $(55-85 \%)$ is predicted, and the prediction results are shown in Figure 11. The traffic frequency of all cases is 1000/day. It can be seen from Figure 11 that the increase of environmental temperature and relative humidity will reduce the corrosion-fatigue life.

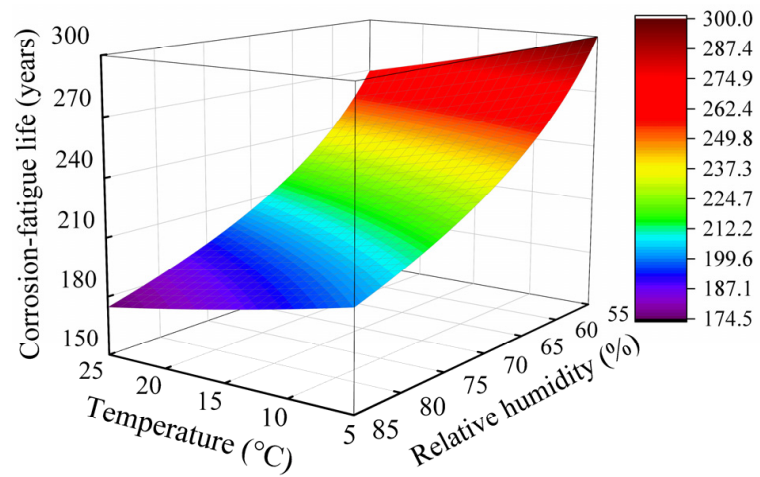

(a)

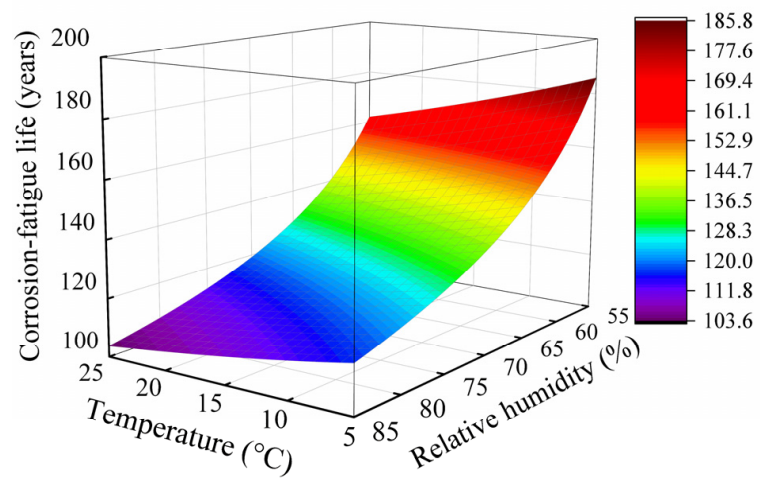

(c)

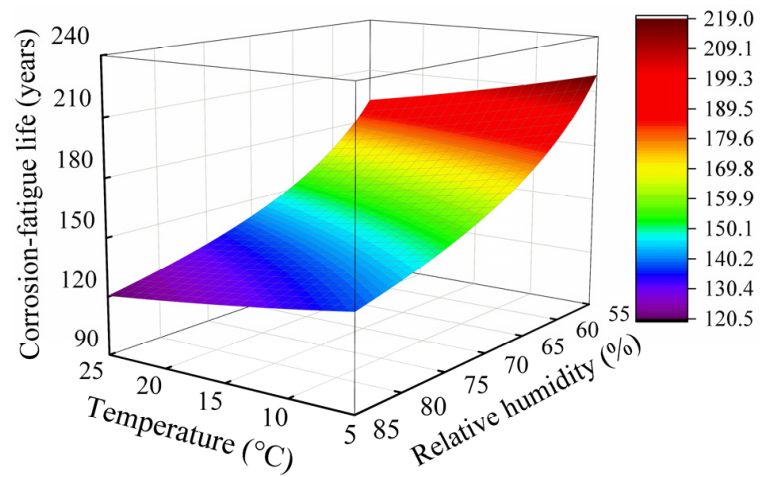

(b)

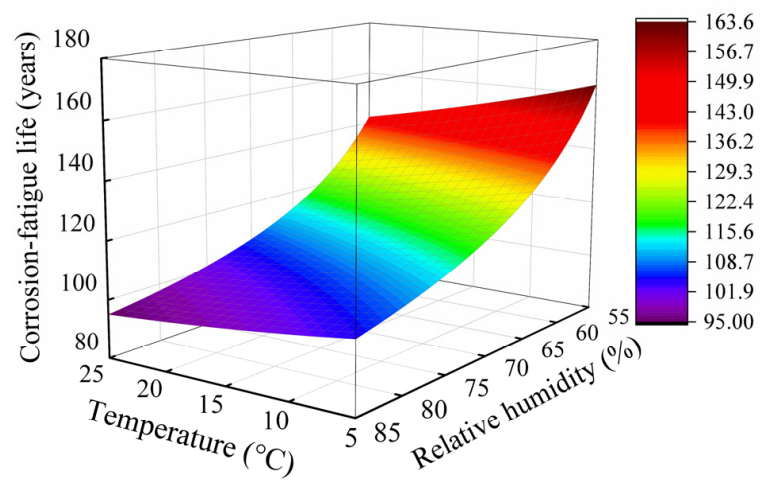

(d)

Figure 11. Corrosion-fatigue life with different environmental temperatures and relative humidity under the carbonation environment grades (a) A, (b) B, (c) C, and (d) D. 
For the environmental temperatures from $5{ }^{\circ} \mathrm{C}$ to $25^{\circ} \mathrm{C}$ and environmental relative humidity from $55 \%$ to $85 \%$, the corrosion-fatigue life of the RC slab is $299.9-174.7$ years, 218.9-120.5 years, 185.8-103.7 years, and 163.5-95.0 years, respectively, under carbonation environment grades A to D. The service conditions with different environmental temperatures and relative humidity will reduce the corrosion-fatigue life by up to $41.76 \%, 44.95 \%$, $44.16 \%$, and $41.87 \%$, under the four different carbonation environment grades A to D.

\section{Conclusions}

The current study proposed a novel corrosion-fatigue life prediction model for RC structures under coupled carbonation and repeated loading. The proposed corrosionfatigue life prediction model was illustrated by a $6 \mathrm{~m}$-span RC slab in a simply supported slab bridge for the highway. The fatigue damage and the corrosion-fatigue life were predicted. The influences of traffic frequency, overloading, carbonation environment grade, and environmental temperature and relative humidity were analyzed. The following conclusions can be drawn:

(1) The proposed corrosion-fatigue life prediction model can predict the corrosion-fatigue life simply and conveniently for RC structures under coupled carbonation and repeated loading.

(2) Under the design service condition, the corrosion-fatigue performance of the $6 \mathrm{~m}$-span $\mathrm{RC}$ slab is satisfactory. The cumulative fatigue damage in the tensile reinforcement at the slab bottom is 0.372 when the bridge is operated to the design service life, and the corrosion-fatigue life of the RC slab is 162.1 years.

(3) The increase of traffic frequency and overloading ratio will reduce the corrosionfatigue life of the $6 \mathrm{~m}$-span RC slab. When the traffic frequency increases from 1000 /day to $7000 /$ day, the corrosion-fatigue life will decrease by $66.86 \%$. When the overloading ratio increases from $0 \%$ to $20 \%$, the corrosion-fatigue life will decrease by $58.90 \%$.

(4) The corrosion-fatigue life of the $6 \mathrm{~m}$-span RC slab decreases with the increase of carbonation environment grade. Compared with the carbonation-free environment, the four carbonation environments grades A, B, C, and D will reduce the corrosionfatigue life by $56.48 \%, 69.67 \%, 74.46 \%$, and $77.45 \%$, respectively.

(5) The increase of environmental temperature and relative humidity will reduce the corrosion-fatigue life of the $6 \mathrm{~m}$-span RC slab. Under the four different carbonation environment grades of $\mathrm{A}$ to $\mathrm{D}$, the increase of environmental temperature and relative humidity can reduce the corrosion-fatigue life by up to $41.76 \%, 44.95 \%, 44.16 \%$, and $41.87 \%$, respectively.

Author Contributions: Conceptualization, C.C. and L.S.; Methodology, C.C.; Software, C.C. and J.L.; Validation, C.C. and J.L.; Formal Analysis, C.C.; Investigation, C.C.; Resources, L.S. and Z.Y.; Data Curation, J.L.; Writing-Original Draft Preparation, C.C.; Writing-Review \& Editing, L.S.; Visualization, C.C.; Supervision, L.S.; Project Administration, L.S. and Z.Y.; Funding Acquisition, L.S. All authors have read and agreed to the published version of the manuscript.

Funding: Financial support provided by the National Natural Science Foundation of China (Grant Nos. 51778631, 52078492, and U1934217), the Scientific Research Project of Shuohuang Railway Development Co., Ltd. (Grant No. SHGF-18-50), and the Major Research Project of China Railway Group Limited (Grant No. 2020-Major-2) are greatly appreciated.

Institutional Review Board Statement: Not applicable.

Informed Consent Statement: Not applicable.

Data Availability Statement: Not applicable.

Conflicts of Interest: The authors declare no conflict of interest. 


\section{References}

1. Hrabová, K.; Lehner, P.; Ghosh, P.; Konečný, P.; Teplý, B. Sustainability Levels in Comparison with Mechanical Properties and Durability of Pumice High-Performance Concrete. Appl. Sci. 2021, 11, 4964. [CrossRef]

2. Bheel, N.; Tafsirojjaman, T.; Liu, Y.; Awoyera, P.; Kumar, A.; Keerio, M.A. Experimental Study on Engineering Properties of Cement Concrete Reinforced with Nylon and Jute Fibers. Buildings 2021, 11, 454. [CrossRef]

3. Lu, Y.; Tang, W.; Li, S.; Tang, M. Effects of simultaneous fatigue loading and corrosion on the behavior of reinforced beams. Constr. Build. Mater. 2018, 181, 85-93. [CrossRef]

4. Song, L.; Hou, J.; Yu, Z. Fatigue and post-fatigue monotonic behaviour of partially prestressed concrete beams. Mag. Concrete Res. 2016, 68, 109-117. [CrossRef]

5. $\quad$ Lantsoght, E.O.L.; Koekkoek, R.; Vander, V.C.; Sliedrecht, H. Fatigue Assessment of Prestressed Concrete Slab-Between-Girder Bridges. Appl. Sci. 2019, 9, 2312. [CrossRef]

6. Kumar, V. Protection of steel reinforcement for concrete-A review. Corros. Rev. 1998, 16, 317-358. [CrossRef]

7. Lee, H.; Lee, H.; Min, S.; Lim, S.; Singh, J. Carbonation-induced corrosion initiation probability of rebars in concrete with/without finishing materials. Sustainability 2018, 10, 3814. [CrossRef]

8. Wu, J.; Diao, B.; Xu, J.; Zhang, R.; Zhang, W. Effects of the reinforcement ratio and chloride corrosion on the fatigue behavior of RC beams. Int. J. Fatigue 2020, 131, 105299. [CrossRef]

9. Song, L.; Yu, Z. Fatigue performance of corroded reinforced concrete beams strengthened with CFRP sheets. Constr. Build. Mater. 2015, 90, 99-109. [CrossRef]

10. Blikharskyy, Y.; Selejdak, J.; Kopiika, N. Corrosion fatigue damages of rebars under loading in time. Materials 2021, 14, 3416. [CrossRef]

11. Bigaud, D.; Ali, O. Time-variant flexural reliability of RC beams with externally bonded CFRP under combined fatigue-corrosion actions. Reliab. Eng. Syst. Saf. 2014, 131, 257-270. [CrossRef]

12. Koh, T.; Kim, M.; Yang, K.; Yoon, Y.; Kwon, S. Service life evaluation of RC T-girder under carbonation considering cold joint and loading effects. Constr. Build. Mater. 2019, 226, 106-116. [CrossRef]

13. Kwon, S.; Na, U. Prediction of durability for RC columns with crack and joint under carbonation based on probabilistic approach. Int. J. Concr. Struct. Mater. 2011, 5, 11-18. [CrossRef]

14. Jiang, Z.; Gu, X.; Huang, Q.; Zhang, W. Statistical analysis of concrete carbonation depths considering different coarse aggregate shapes. Constr. Build. Mater. 2019, 229, 116856. [CrossRef]

15. Song, L.; Liu, J.; Cui, C.; Yu, Z.; Fan, Z.; Hou, J. Carbonation process of reinforced concrete beams under the combined effects of fatigue damage and environmental factors. Appl. Sci. 2020, 10, 3981. [CrossRef]

16. Liu, Z.; Philip, V.D.H.; Belie, N.D. Effect of the mechanical load on the carbonation of concrete: A review of the underlying mechanisms, test methods, and results. Materials 2021, 14, 4407. [CrossRef] [PubMed]

17. Wu, J.; Zhang, R.; Diao, B.; Zhang, W.; Xu, J. Effects of pre-fatigue damage on high-cycle fatigue behavior and chloride permeability of RC beams. Int. J. Fatigue 2019, 122, 9-18. [CrossRef]

18. Ma, Y.; Xiang, Y.; Wang, L.; Zhang, J.; Liu, Y. Fatigue life prediction for aging RC beams considering corrosive environments. Eng. Struct. 2014, 79, 211-221. [CrossRef]

19. Li, Y.; Chen, Y.; Shao, W.; Zhang, J.; Liao, S.; Fernandez-Steeger, T.M. Service life prediction and lateral bearing capacity analysis of piles considering coupled corrosion-temperature deterioration processes. J. Mar. Sci. Eng. 2021, 9, 614. [CrossRef]

20. Sun, J.; Ding, Z.; Huang, Q. Corrosion fatigue life prediction for steel bar in concrete based on fatigue crack propagation and equivalent initial flaw size. Constr. Build. Mater. 2019, 195, 208-217. [CrossRef]

21. Yang, D.; Yi, T.; Li, H. Coupled fatigue-corrosion failure analysis and performance assessment of RC bridge deck slabs. J. Bridge Eng. 2017, 22, 4017077. [CrossRef]

22. Wang, X. Effects of crack and climate change on service life of concrete subjected to carbonation. Appl. Sci. 2018, 8, 572. [CrossRef]

23. Marques, P.F.; Costa, A. Service life of RC structures: Carbonation induced corrosion. Prescriptive vs. performance-based methodologies. Constr. Build. Mater. 2010, 24, 258-265. [CrossRef]

24. Chen, Y.; Liu, P.; Yu, Z. Effects of environmental factors on concrete carbonation depth and compressive strength. Materials 2018, 11, 2167. [CrossRef]

25. Wang, J.; Zheng, W.; Zhao, Y.; Zhang, X. Time-varying reliability evaluation of concrete based on carbonation Depth. Appl. Sci. 2019, 9, 5116. [CrossRef]

26. Rastayesh, S.; Mankar, A.; Dalsgaard Sørensen, J.; Bahrebar, S. Development of stochastic fatigue model of reinforcement for reliability of concrete structures. Appl. Sci. 2020, 10, 604. [CrossRef]

27. Al-Rousan, R.; Issa, M. Fatigue performance of reinforced concrete beams strengthened with CFRP sheets. Constr. Build. Mater. 2011, 25, 3520-3529. [CrossRef]

28. Ganesh, P.; Ramachandra Murthy, A. Fatigue performance of damaged RC beams rehabilitated with GGBS based ultra high performance concrete. Int. J. Fatigue 2020, 138, 105707. [CrossRef]

29. Sun, J.; Ding, Z.; Huang, Q. Development of EIFS-based corrosion fatigue life prediction approach for corroded RC beams. Eng. Fract. Mech. 2019, 209, 1-16. [CrossRef]

30. Li, S.; Tang, H.; Gui, Q.; Ma, Z. Fatigue behavior of naturally corroded plain reinforcing bars. Constr. Build. Mater. 2017, 152, 933-942. [CrossRef] 
31. Jiang, C.; Huang, Q.; Gu, X.; Zhang, W. Experimental investigation on carbonation in fatigue-damaged concrete. Cement. Concrete Res. 2017, 99, 38-52. [CrossRef]

32. Jiang, C.; Huang, Q.; Gu, X.; Zhang, W. Modeling the effects of fatigue damage on concrete carbonation. Constr. Build. Mater. 2018, 191, 942-962. [CrossRef]

33. Zhang, W.; Ye, Z.; Gu, X.; Liu, X.; Li, S. Assessment of fatigue life for corroded reinforced concrete beams under uniaxial bending. J. Struct. Eng. 2017, 143, 4017048. [CrossRef]

34. Verma, M.; Mishra, S.S. Coupled fatigue-corrosion life estimation of reinforced concrete beam: Numerical versus experimental approach. Struct. Concrete 2019, 20, 2194-2205. [CrossRef]

35. Bastidas-Arteaga, E.; Bressolette, P.; Chateauneuf, A.; Sanchez-Silva, M. Probabilistic lifetime assessment of RC structures under coupled corrosion-fatigue deterioration processes. Struct. Saf. 2009, 31, 84-96. [CrossRef]

36. $\mathrm{Wu}$, J.; Xu, J.; Diao, B.; Jin, L.; Du, X. Fatigue life prediction for the reinforced concrete (RC) beams under the actions of chloride attack and fatigue. Eng. Struct. 2021, 242, 112543. [CrossRef]

37. Ge, B.; Kim, S. Probabilistic service life prediction updating with inspection information for RC structures subjected to coupled corrosion and fatigue. Eng. Struct. 2021, 238, 112260. [CrossRef]

38. Song, L.; Cui, C.; Liu, J.; Yu, Z.; Jiang, L. Corrosion-fatigue life assessment of RC plate girder in heavy-haul railway under combined carbonation and train loads. Int. J. Fatigue 2021, 151, 106368. [CrossRef]

39. Zhang, Q. Mathematical modeling and numerical study of carbonation in porous concrete materials. Appl. Math. Comput. 2016, 281, 16-27. [CrossRef]

40. Papadakis, V.G.; Fardis, M.N.; Vayenas, C.G. Effect of composition, environmental factors and cement-lime mortar coating on concrete carbonation. Mater. Struct. 1992, 25, 293-304. [CrossRef]

41. Song, H.; Kwon, S.; Byun, K.; Park, C. Predicting carbonation in early-aged cracked concrete. Cement. Concrete Res. 2006, 36, 979-989. [CrossRef]

42. GB50010-2010. Code for Design of Concrete Structures; China Architecture \& Building Press: Beijing, China, 2015. (In Chinese)

43. Papadakis, V.G.; Vayenas, C.G.; Fardis, M.N. Fundamental modeling and experimental investigation of concrete carbonation. ACI Mater. J. 1991, 88, 363-373.

44. Wang, X.; Zhang, W.; Gu, X.; Dai, H. Determination of residual cross-sectional areas of corroded bars in reinforced concrete structures using easy-to-measure variables. Constr. Build. Mater. 2013, 38, 846-853. [CrossRef]

45. GB/T 51355-2019. Standard for Durability Assessment of Existing Concrete Structures; China Architecture \& Building Press: Beijing, China, 2019. (In Chinese)

46. Li, J. Study on Fatigue Mechanics Behavior of Prestressed Concrete Bridges. Ph.D. Thesis, Central South University, Changsha, China, 2013. (In Chinese).

47. Miner, M.A. Cumulative damage in fatigue. J. Appl. Mech. 1945, 12, A159-A164. [CrossRef]

48. Ma, Y.; Wang, G.; Su, X.; Wang, L.; Zhang, J. Experimental and modelling of the flexural performance degradation of corroded RC beams under fatigue load. Constr. Build. Mater. 2018, 191, 994-1003. [CrossRef]

49. Li, H.; Frangopol, D.M.; Soliman, M.; Xia, H. Fatigue reliability assessment of railway bridges based on probabilistic dynamic analysis of a coupled train-bridge system. J. Struct. Eng. 2016, 142, 4015158. [CrossRef]

50. Li, X.; Wang, Z.; Ren, W. Time-Dependent Reliability Assessment of Reinforced Concrete Bridge under Fatigue Loadings. China Railw. Sci. 2009, 30, 49-53. (In Chinese)

51. EN 1992-1-1 Eurocode 2: Design of Concrete Structures. General Rules. Rules for Buildings; European Committee for Standardization (CEN): Brussels, Belgium, 2014.

52. Yan, D.; Luo, Y.; Lu, N.; Yuan, M.; Beer, M. Fatigue stress spectra and reliability evaluation of short-to medium-span bridges under stochastic and dynamic traffic loads. J. Bridge Eng. 2017, 22, 04017102. [CrossRef]

53. Deng, L.; Yan, W.; Nie, L. A simple corrosion fatigue design method for bridges considering the coupled corrosion-overloading effect. Eng. Struct. 2019, 178, 309-317. [CrossRef]

54. Bastidas-Arteaga, E. Reliability of reinforced concrete structures subjected to corrosion-fatigue and climate change. Int. J. Concr. Struct. Mater. 2018, 12, 77-89. [CrossRef] 